ROCZNIKI NAUK SPOŁECZNYCH

Tom 11(47), numer 2 - 2019

DOI: http://dx.doi.org/10.18290/rns.2019.47.2-6

ANNA MATUSZEWSKA

\title{
E-SERVICES VS CONCERN FOR THE IMAGE OF ZUS
}

\section{INTRODUCTION}

In the vast majority of cases the Polish Social Insurance Institution (Zakład Ubezpieczeń Społecznych, ZUS) is perceived as an independent creation, which not only is unable to decide about the rate of fees and the shape of pension scheme but also who to grant a benefit to and at what amount. The information that we hear almost daily about the operations of ZUS is interpreted in various ways, depending on the source. More often than not, a particular interpretation depends on the feelings of an individual customer. The dissemination of many unfavourable opinions very often depends on the amount of the benefit granted, disregarding all other aspects. Social mechanisms play a major role in creating the image of ZUS, which nothing but spread second-hand information, press news or information published by different media.

The submitted study presents the current proposals of ZUS in the field of e-services, which confirms its endeavours to become an innovative institution of public trust, which constitute an inherent part of the premise of new public management.

The Electronic Service Platform (Platforma Ustug Elektronicznych, PUE), e-Contribution (E-Sktadka), and electronic sick leave certificates have become a matter of great interest for the author of this article. PUE is the first Polish e-office, launched in 2012. Thanks to it, today we can show the results of several years' experience gained from the use of this tool. However, e-services in general and e-Contribution in particular are current proposals of electronic services offered by ZUS, but even today we can try to

Anna MatuszewsKa, PhD, President Stanisław Wojciechowski State University of Applied Sciences in Kalisz; address for correspondence: ul. Nowy Świat 4, 62-800 Kalisz, Poland; e-mail: a.matuszewska@pwsz-kalisz.edu.pl; https://orcid.org/0000-0002-4450-779X. 
sum up the first months of the functioning of these e-services. A research question that remains to be asked is one about the degree in which the implemented e-services influence the quality of services offered, customers' satisfaction, and ultimately how all that influences the image of ZUS. We will try to prove that ZUS is ready to serve customers remotely by offering a number of innovative solutions. Some problems may occur in a situation where clients have no or little knowledge of this subject, do not want to change their current habits or simply have no interest in them. There is no doubt that e-projects realized by ZUS are an inherent aspect of New Public Management.

\section{NEW PUBLIC MANAGEMENT}

For a dozen or so years, we can observe that the Polish public administration has implemented quality changes, which rely on a practical application of modern methods of management. Those changes are linked with the concept of New Public Management, which is quality oriented. The new approach to managing the public sector assumes that the success of entities of the public sector can be measured by the effective satisfaction of people's needs. ${ }^{1}$

The expected result of such activities is better utilization of resources, application of specific organizational standards as well as increased citizen/customer satisfaction with the quality of the services offered. ${ }^{2}$ Despite a lack of the explicit concept of quality it is undoubtedly something that the client expects. Quality is the degree of fulfilment of client's expectations. They can be payers, insured individuals and beneficiaries. The quality of services provided by ZUS undoubtedly affects the image of the whole organization and it must be constantly improved.

By presenting the essence of the concept of New Public Management, one must bear in mind the fact that clients who are used to high-quality services offered by numerous companies, have got higher and higher expectations. They expect at least a similar level of quality of services provided by office workers, and they are becoming increasingly critical of evaluating the way public offices function as well as of entities providing public services.

\footnotetext{
${ }^{1}$ Nowe zarzadzanie publiczne - skuteczność i efektywność, ed. T. Lubińska (Warsaw: Difin 2009), 281.

${ }^{2}$ Kierunki doskonalenia koncepcji zarzadzania organizacja publiczna, ed. B. Lubas, D. Hryszkiewicz, and M. Borowik (Szczytno: Wyższa Szkoła Policji w Szczytnie, 2016), 247.
} 
E-services constitute a fairly modern concept. The advancement level of virtual administration can be illustrated using individual stages of electronic service delivery:

- the first stage (on-line information) makes it possible to find information about a specific topic and the services that it provides on its official website;

- the second stage (unidirectional interaction) makes it possible to search for information and download official forms from the website;

- the third stage (bidirectional interaction) makes it possible to search for information, download forms, fill them in and submit electronically;

- the fourth stage (so-called transaction) makes it possible to complete a service of process. The client completes all actions - such as obtaining information, downloading and filing in appropriate forms, and sending them back with an electronic signature. The client can also pay appropriate charges, receive a certificate, permission or other official document they request. ${ }^{3}$

Modern institutions should base their operations on the ability to identify the basic organizational processes, on improving the above processes and efforts to provide services organized in the best possible way. At the same time, an efficient institution is able to manage change, diagnose and analyse its clients' needs, launch innovations and continually improve and develop ways of service. ZUS is undertaking every now and again new actions to improve its standards of customer care by offering numerous e-solutions. However, it is worth asking to what extent the implemented facilities are customized. ZUS clients differ in terms of gender, age, marital status, form of employment, form of their business operation and many other criteria. All of this can make it hard to recognize the real needs, search for optimal solutions and implement specific solutions.

\section{E-SERVICES AT ZUS}

In the second decade of the 21 st century, ZUS implemented modern methods of management based on solutions employed by many companies. The basis for this change is enshrined in the following strategic documents (in Polish):

\footnotetext{
${ }^{3}$ M. ZAWICKI, Nowe zarządzanie publiczne (Warsaw: Polskie Wydawnictwo Ekonomiczne, 2011), 65 .
} 
- ZUS transformation strategy for the years 2010-2012, aimed mainly at increasing client satisfaction thanks to the implementation of innovative solutions in the service sector; ${ }^{4}$

- ZUS development strategy for the years 2013-2015, which became the basis for the implementation of new solutions aimed at increasing the quality of customer service as well as expanding the range of electronic services; ${ }^{5}$

- ZUS strategy for the years 2016-2020, which, while observing the assumptions approved in the previous strategic documents, determines new values and directions of development, crucial to the growth of ZUS. ${ }^{6}$

The latter document provides that "the vision of ZUS is to reach the status of an innovative institution of public trust," whereas the mission statement goes like this: "Efficient, friendly and reliable customer service accomplished in accordance with the provisions of the law, rules of rational and transparent financial resources management, using modern technologies and the potential of its employees."

Based on the ZUS vision and mission statement and on the results of strategic diagnosis, numerous operational goals have been defined, which at the same time constitute a map of goals see Figure 1 on the following page.

\footnotetext{
${ }^{4}$ ZUS, "Strategia przekształceń Zakładu Ubezpieczeń Społecznych na lata 2010-2012" Warsaw, October 2010, https://www.zus.pl/documents/10182/0/Strategia+2010+-+2012/61d951 0f-241b- 4547-8f73-7455dbf0389c.

${ }^{5}$ ZUS, "Strategia rozwoju Zakładu Ubezpieczeń Społecznych na lata 2013-2015" Warsaw, December 2012, https://www.zus.pl/documents/10182/39611/Strategia+rozwoju+Zak\%C5\%82a $\mathrm{du}+$ Ubezpiecze $\% \mathrm{C} 5 \% 84+$ Spo\%C5\%82ecznych+na+lata+2013-2015/6cb0b2d7-2df2-4bc9-b99f-d d8eb46e2848.

${ }^{6}$ ZUS, "Strategia Zakładu Ubezpieczeń Społecznych na lata 2016-2020” Warsaw, December 2015, https://www.zus.pl/documents/10182/0/Strategia+Zak\%C5\%82adu+Ubezpiecze $\%$ C5\%84+ Spo\%C5\%82ecznych+na+lata+2016+-+2020/cd2987fa-686c-417a-a351-91904dc5ff84.

${ }^{7}$ Ibid., 9.
} 


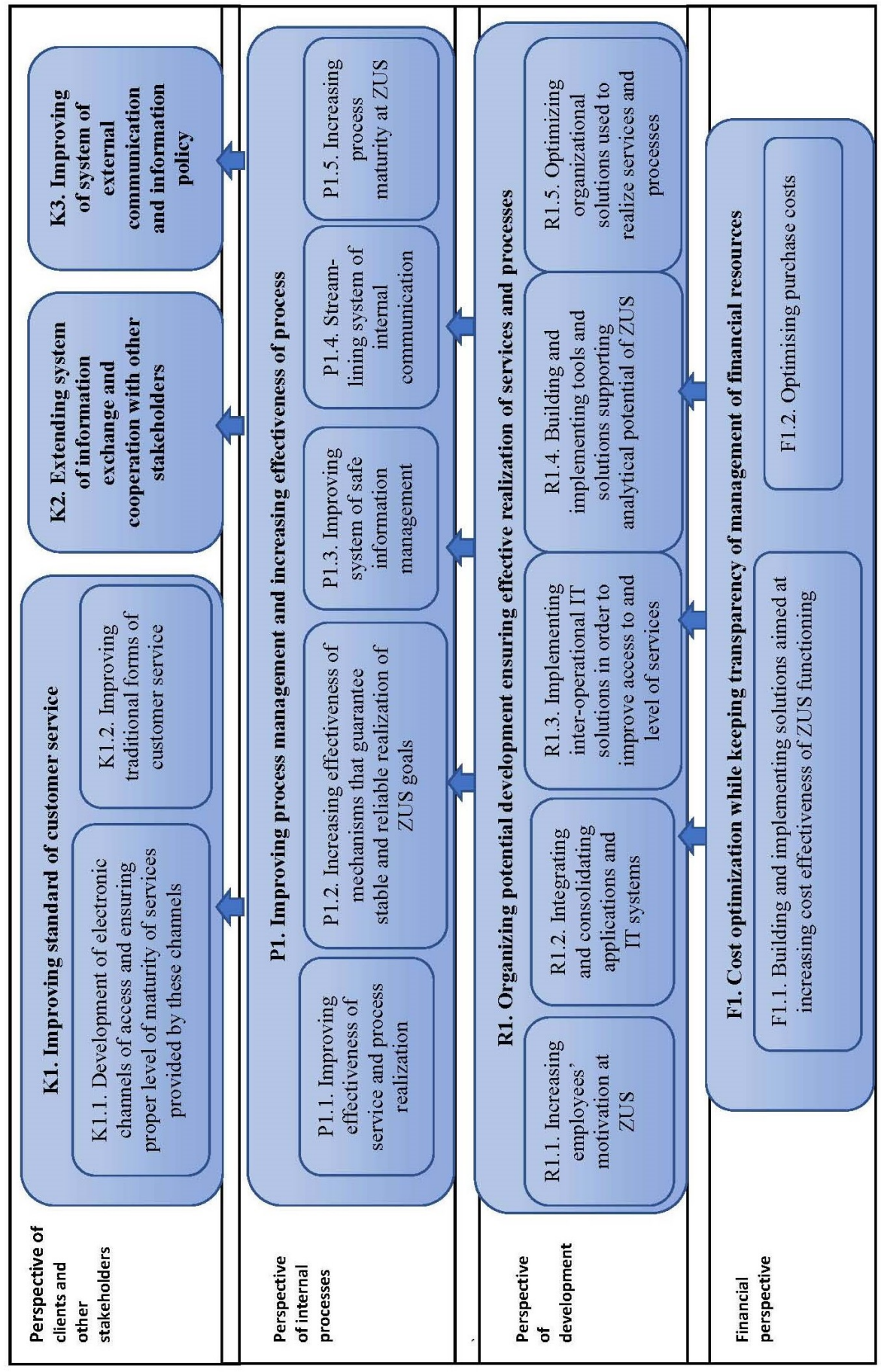

Figure 1. The ZUS map of goals and strategies for the years 2016-2020 
The principal goal is to improve customer care standards. To this end, all kinds of organised actions will be taken at all ZUS branches, and the catalogue of issues that can be fully resolved during a single visit to Biuro $O b$ stugi Klienta (Customer Service Office, $B O K$ ). However, apart from improving the traditional forms of contact, ZUS is continuously developing its electronic services. It should be noted that the aim is also to ensure an adequate quality of services provided via electronic channels.

\section{ELECTRONIC SERVICE PLATFORM}

In June 2012, the first Polish e-office was launched, called Platforma Ustug Elektronicznych (Electronic Services Platform, PUE). It is a real breakthrough, especially from the point of view of clients, who - by having access to the Internet - are able to deal with insurance matters without having to personally visit a ZUS office. It seems that in the digital age and with many services going electronic such solutions are becoming a standard. PUE constitutes an alternative form of contact with ZUS branch offices and a tool which is especially helpful for those people who, for various reasons, give up a traditional visit and switch to the electronic platform. ${ }^{8}$ It is worth highlighting that the year-on-year number of clients using the PUE platform is increasing, and the platform itself is continuously being updated and expanded with new options and possibilities.

By opening an account on the platform, the client gains access to his or her data and can analyse the data that is stored on their individual ZUS account. What is more, the client can arrange a personal visit to a ZUS branch as well as check if they have been entered on a list of insured employees by their employer. A very interesting option is offered by the calculator utility, which enables to predict one's future pension benefit. The platform also makes it possible to submit forms related to the government program Family 500+.

It should be pointed out that contribution payers have access to slightly different options offered by the PUE platform than, for example, insured persons or beneficiaries. The ZUS website offers a wealth of information and definitions.

- Insured person (e.g., employee) can see if the contribution payer entered him or her and their family members on a list of insured employees.

\footnotetext{
${ }^{8}$ M. NiEDZIELA, "Zakład Ubezpieczeń Społecznych zmienia się dla klienta," in Wybrane aspekty ubezpieczeń społecznych, ed. A. Matuszewska (Kalisz: Wydawnictwo PWSZ, 2018), 141.
} 
They can also check their ZUS account balance or calculate a pension forecast. What is more, they can also get information about sick leaves sent to ZUS so far.

- Contribution payer (e.g., entrepreneur) can get a tax clearance certificate and have access to the declaration submitted and payment statement. Small and medium-sized entrepreneurs have the option of generating and sending completed insurance documents to ZUS.

- Beneficiary can check his or her ZUS ZLA medical certificate and check detailed information about national insurance benefit that they receive. $^{9}$

As of December 31,2017, as many as 2,032,090 clients had their personal PUE accounts:

- insured individuals: $1,978,610$

- contribution payers: $1,614,994$

- beneficiaries: $1,010,143$

- physicians: 42,065

- debt collectors: $1,902 .{ }^{10}$

As of June 3, 2018, as many as 2,311,522 clients had registered profiles on PUE ZUS.

The awards granted to ZUS for the PUE platform clearly indicate how important it is for clients to have access to high quality electronic services at ZUS. The insurer received the Lider informatyki 2012 award (IT Leader 2012 Award) for launching the platform. In 2014, PUE was considered to be the top quality product and was awarded a quality mark called Quality International 2014. ${ }^{11}$ On April 18, 2016, PUE - as a modern and convenient form of communication with ZUS - was awarded Certificate of Merit in a competition organized by the International Social Security Association.

\section{E-SICK LEAVE}

PUE is being extended by means of new functionalities. As of January 1 , 2016, doctors have the possibility of issuing e-sick leave certificates (e-ZLA), which extremely convenient for sick persons, who are no longer obliged to

\footnotetext{
${ }^{9}$ This is information is provided on www.zus.pl/baza-wiedzy, under the "Baza wiedzy" (Knowledge Base) tab. Accessed June 1, 2018.

${ }^{10}$ Author's correspondence with the Customer Service Department by letter of March 19, 2018 (data for 2017).

${ }^{11}$ ZUS, “Obsługa klientów w ZUS. Polityka 2017-2020. Informacja z 2016 r.” Warsaw 2016.
} 
deliver a hard copy of the sick leave to their employer. The electronic version of the sick leave is automatically delivered to both the employer and ZUS. In accordance with the current legislation, since December 1, 2018 all physicians who are granted authorization to issue certificates of temporary incapacity for work will be obliged to issue such a document - only in an electronic version. The first idea was that e-ZLA was to be up and running as of July 1, 2018; however, obstacles, doubts and discussions of the interested parties postponed the launch date. Implementation of e-ZLA became a top priority project because all the facilities weigh in favour of patients, employers and physicians. An additional argument can be the fact that from January 1, 2016 to the end of October 2017, physicians issued 1.4 million e-ZLA certificates - which accounts for 3\% of all sick leaves granted. ${ }^{12}$

In general, granting such leave lasts shorter than in the case of the traditional sick leave in paper form. After entering the patient's (insured person) national identity number (PESEL), the physician gets access to all data that is necessary to issue a e-ZLA certificate. ${ }^{13}$ Issuance of e-ZLA documents is also available for mobile devices, for example during a private house visit. The possibility of monitoring ongoing sick leaves of a given patient is undoubtedly a great convenience. Additionally, the system reminds physicians about the possibility of placing a patient on a rehabilitation scheme as pension prevention supported by ZUS. After approving a physician's decision to give a patient a rehabilitation placement, the system brings up the ZUS PR-4 form and automatically fills up a given form with patient's data. Then the physician can issue application for rehabilitation and send it to ZUS in an electronic form in order to issue a medical certificate by a doctor representing ZUS.

An electronic sick leave is sent to both ZUS and the employer, and the patient is no longer obliged to meet the seven-day deadline for delivering his or her sick leave to the workplace. ZUS is taking intensive measures aimed at informing and promoting knowledge of e-ZLA among all interested groups (patients, employers, physicians and ZUS employees). During numerous conferences, trainings, workshops and direct meetings, all information and instructions are passed. However, it seems that the biggest problem ZUS is still facing is physicians' opposition. Frequently, during appointments, physicians present an attitude that could be described at least as reluctant or

\footnotetext{
${ }^{12}$ ZUS, "E-ZLA - jedyny sposób na wystawienie zwolnienia," Z życia ZUS, no. 11-12 (2017).

${ }^{13}$ M. BugaJ-WojciechowsKa, "E-ZLA - ułatwienia dla pracowników, pracodawców i lekarzy," Z życia ZUS, no. 9 (2015): 1.
} 
they are completely uninterested in giving information and promoting activity. "The electronic doctor's leave is a convenient solution for patients. If some doctors do not want to implement them, it is because they only think about their own comfort." ${ }^{14}$ However, from the perspective of all beneficiaries, their aversion to implementing e-ZLA is unfounded.

Lower costs of service, speed, simplicity and convenient access to information are but a few of the numerous functionalities the European citizens have when using e-sick leave. The benefits are not only perceived by patients but also doctors and employers. During a seminar organized by ZUS called "Electronic sick leave - the international experience," speakers from Sweden, Italy, Lithuania and Russia shared their own experiences concerning the implementation and practical use of e-sick leave. In Sweden, e-sick leave certificates are used in $95 \%$ of cases because this form is much more convenient, and paper sick leave certificates are only issued in exceptional situations. In 2010, Lithuanians implemented the sick leave in the compulsory electronic form, limiting the transition period to just two months. At present, it is impossible to issue sick leave certificates on paper. On the other hand, the failure to abide by the law related to e-sick leave in Italy can result in physicians being fined up to having their contracts terminated. Statistically, $98 \%$ of sick leave certificates are issued electronically there. In addition, Italians devised a system, thanks to which a physician can contact a dedicated "Call Centre" and register an e-sick leave certificate by phone in the event of any system failure. Russians, on the other hand, are having a hard time implementing the e-sick leave, but it should be noted that $45 \%$ of institutions are now ready and connected to the electronic sick-leave system. ${ }^{15}$ Considering the experience of other countries as well as the convenience of the proposed solution, it seems that Polish physicians should appreciate the positive aspects of e-ZLA.

\section{E-CONTRIBUTION}

As of January 1, 2018, one of the most modern e-services called e-Contribution, was launched. This and easy payments at ZUS offices are solutions

${ }^{14}$ J. WatoŁA, "Elektroniczne zwolnienia? Spokojnie, doktorze, to tylko computer," Gazeta Wyborcza, January 26, 2018, https://wyborcza.pl/TylkoZdrowie/7,137474,22936971, elektronicznezwolnienia -spokojnie-doktorze-to-tylko.html.

${ }^{15}$ Information provided on the ZUS website; data accessed June 2, 2018. 
which are used mainly by entrepreneurs. The main idea of the project is to enable single-payment contributions instead of three or four bank operations, as used to be the case. A contribution payer can effect a single transfer to cover all the fees:

- social insurance

- health insurance

- Labour Fund

- Fund of Guaranteed Employees' Benefits

- Bridging Pension Fund.

Under the project, all current bank account for contributions were closed as of December 31, 2017, and new bank accounts were created - personal accounts for individual payers, who now can pay all financial obligations towards ZUS using one standardized payment document, transferring money to individual account number for ZUS contributions (NRS). Individual account number for contributions consists of 26 digits and was sent to every payer of ZUS contributions to the company seat or to a forwarding address. Approximately 3.5 milion of letters containing such information were sent between October 1 and December 31, 2017. As of now, each entrepreneur can check their NRS number online. The structure of the account number for contributions is the following:

Figure 2. The structure of the individual account number for contributions (numer rachunku skladkowego, NRS)

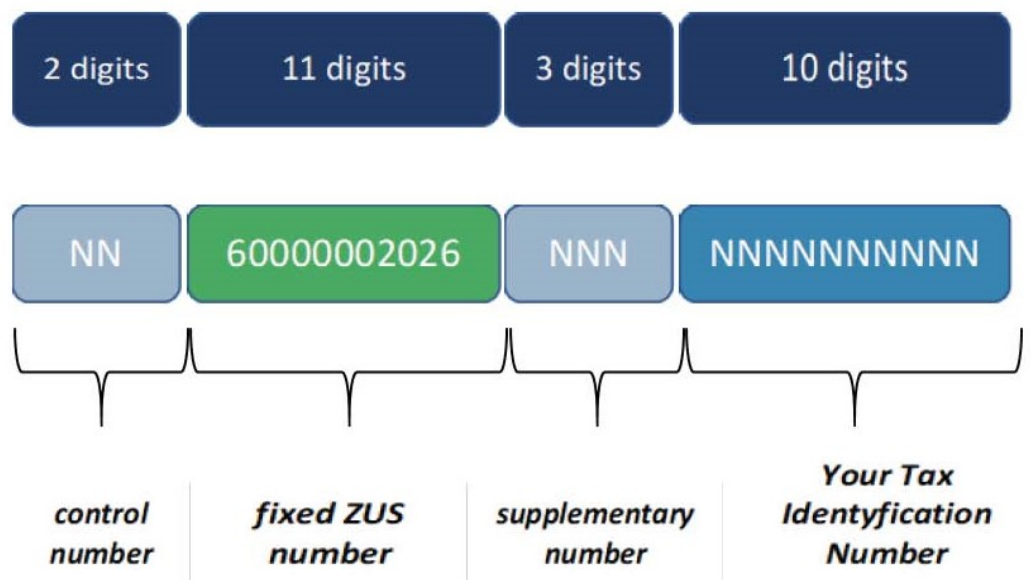

Source: www.zus.pl/eskladka (as of June 2018). 
What is worth highlighting is the fact that when contribution payers make a payment, they do not need to give identification details, period and type of payment, type of insurance or the name of the fund to which the payment is assigned. First e-contributions were received by ZUS as early as on January 2, 2018, and in the opinion of Minister of Family, Labour and Social Policy Elżbieta Rafalska and Gertruda Uścińska, the President of ZUS, they bring positive and satisfying effects. "We note with satisfaction that our grand project aimed at organizing this side of the social insurance pillar, as far as revenues are concerned, is coming true." "For a deeper analysis, we need to say that since January 1, there has been a change in the way the balance of payments is settled. In practice, it means that each late payment will eliminate entrepreneur from voluntary health insurance. Not all entrepreneurs (contribution payers) participated in briefings organized since September 2017, and this is why public awareness of this fact may be low. Previously, payments made were settled in accordance with the description on the payment document - therefore it was the payer who decided about the type of financial obligations he or she settled. In the current system, first there is information about a potential debt that needs to be settled, and only then current financial obligations are settled.

That is the above-mentioned change, which has led to clients' dissatisfaction, as they did not acquaint themselves thoroughly with the current regulations and may find themselves in embarrassing and uncomfortable situation. The positive aspect of this solution is the fact that it can prevent interest for late payments from accruing, which can reduce the financial burden the contribution payer has to deal with. We must not forget about time and money savings for the payers, who now can settle their ZUS payments using only one transfer order.

The e-Contribution project is in the first phase of implementation and expectations related to this project are very high. The main ZUS website boasts that ZUS was granted an award for the e-Contribution system during the 6th International Congress of Non-Cash Payments in the category "Event of the Year in the Cashless World."

One will have to wait a little bit longer for a valid statistical study, which will hopefully indicate in what degree to objective of the so-called e-contributions has been attained.

\footnotetext{
${ }^{16}$ K. WóJCIK, "E-składka bez problemów,” Rzeczpospolita, January 18, 2018. https://archiwum. rp.pl/artykul/1364215-E-skladka-bez-problemow.html.
} 


\section{CONCLUSIONS}

The strategic ZUS documents contain regulations proving that clients and their satisfaction with the service they get is the most important for the Polish Social Insurance Institution, irrespective of the type of contact the client chooses to use. There are numerous possibilities, such as a personal visit, telephone conversation with a Customer Service consultant, or getting in touch via the Interment. By taking a range of actions intended to continuously increase the quality of its services, ZUS is introducing new possibilities and taking a number of actions with the aim of consolidating the positive image. Since ZUS clients have different social status (contribution payer, beneficiary, or insured employee) and represent different age groups, the gamut of solutions in the area of customer service proposed by ZUS has to be wide. It is related to the need for systematic improvement and implementation of new solutions. It is of vast importance that e-services offered can be an obstacle and inconvenience for some groups of people. The reason for such state of affairs are numerous, and this ultimately influences the level of client satisfaction and image of ZUS as a whole. The results of research done in 2016 indicate that contact via the Internet was dominating in the 25-34 age group, whereas senior citizens of 65 or more were ones who used this type of contact the least often. ${ }^{17}$ It does not change the fact that ZUS is prepared to provide service to clients remotely. However, there remains a group of clients who will not be interested in the development of e-services by ZUS.

Taking into consideration the benefits of e-ZLA, it can be concluded that the implementation of this solution is not going to face any barriers. However, a lot of physicians expressed their concern about the obligation which may cause that they will not have enough time to deal with patients. The idea was that dedicated healthcare employees could write out sick leave certificates on paper. Another problematic issue is the necessity to have devices, internet access as well as appropriate software. However, it seems that the reasons indicated above are not as problematic as people's reluctance, which is justified by doctors themselves saying that making out e-sick leave certificates will extend the duration of medical appointments, and in turn, queues for doctors will be longer. It was also Polish Medical Association that supported old solutions, namely paper certificates. Then, it must be stated that the above solution characterized by numerous advantages (transparency with respect to writing out

\footnotetext{
${ }^{17}$ ZUS, “Obsługa klientów w ZUS,” 19-20.
} 
sick leaves as well as to prevent irregularities) is confronted with reluctance, and as a result influences the image of ZUS.

It is worth highlighting that clients use e-services proposed by ZUS more and more often, but still the most common type of contact is a personal visit to a given local office. Thanks to the system called "direct customer service management," numerous positive changes in this area can be seen. ${ }^{18}$ Direct service is available in 323 ZUS local units. Only in 2016, 20.2 million clients visited ZUS local offices, which means that a single Customer Service Office worker processed 530 clients per month on average. ${ }^{19}$

Summing up the above considerations, it cannot be forgotten that numerous factors, such as political decisions and media, shape the image of ZUS. On the basis of the research related to public knowledge of and attitude to social insurance, it is obvious that only $7 \%$ of the respondents present the level of knowledge, which can be described as satisfying. ${ }^{20}$ The insufficient knowledge of the system of social insurance in Poland causes that people's emotions are the main factors when making judgements about ZUS. Nonetheless, it must be clearly stated that ZUS is prepared to deal with clients remotely by means of numerous modern solutions. However, there is one question, namely: will clients want to use such solutions and, more importantly, will they be able to use them?

\section{BIBLIOGRAPHY}

\section{LITERATURE}

BuDZYŃSKI, Wojciech. Public relations, strategia i nowe techniki kreowania wizerunku. Warsaw: Poltext, 2008.

Bugaj-WojciechowsKA, Monika. "E-ZLA - ułatwienia dla pracowników, pracodawców i lekarzy." Z życia ZUS, no. 9 (2015).

InSTYTUT SPRAw PUBLICZNYCh. "Wiedza i postawy wobec ubezpieczeń społecznych. Raport z badań.” Warsaw 2016. https://www.zus.pl/documents/10182/44573/Raport+wiedza+system +emerytalny/040bd2a1-094a-4d97-9d77-e0bddc19e845.

Kierunki doskonalenia koncepcji zarzadzania organizacja publiczna. Edited by Barbara Lubas, Dominik, and Małgorzata Borowik. Szczytno: Wyższa Szkoła Policji w Szczytnie, 2016.

\footnotetext{
${ }^{18}$ M. LeWANDOWSKa ET AL., Rzeczpospolita ubezpieczonych: historia ubezpieczeń spolecznych $w$ Polsce (Warsaw: ZUS, 2017), 76.

${ }^{19}$ Ibid., 76.

${ }^{20}$ ISP, "Wiedza i postawy wobec ubezpieczeń społecznych. Raport z badań,” Warsaw 2016, https://www.zus.pl/documents/10182/44573/Raport+wiedza+system+emerytalny/040bd2a1-094a $-4 \mathrm{~d} 97-9 \mathrm{~d} 77-\mathrm{e} 0 \mathrm{bddc} 19 \mathrm{e} 845$.
} 
Lewandowska, Magdalena, Jacek DzIEKAn, Robert MarczaK, Barbara OwsiaK, Olaf RAwski, and Katarzyna SERDECZNA. Rzeczpospolita ubezpieczonych: historia ubezpieczeń spolecznych w Polsce. Warsaw: ZUS, 2017.

NiEDzIELA, Magdalena. "Zakład Ubezpieczeń Społecznych zmienia się dla klienta.” In Wybrane aspekty ubezpieczeń spolecznych, edited by Anna Matuszewska. Kalisz: Wydawnictwo PWSZ, 2018.

Nowe zarzadzanie publiczne - skuteczność i efektywność. Edited by Teresa Lubińska. Warsaw: Difin, 2009.

SzWAJCA, Danuta. Zarzadzanie reputacja przedsiębiorstwa, Budowa i odbudowa zaufania interesariuszy. Warsaw: CeDeWu, 2016.

Wartości i nowoczesność w strategii odpowiedzialnego rozwoju: nowe ścieżki rozwoju w Europie Środkowej $i$ Wschodniej. Edited by Sławomir Partycki and Roman Sobiecki. Lublin: Wydawnictwo KUL, 2017.

WAtoŁA, Judyta. "Elektroniczne zwolnienia? Spokojnie, doktorze, to tylko komputer." Gazeta Wyborcza, January 26, 2018. https://wyborcza.pl/TylkoZdrowie/7,137474,22936971,elektro niczne-zwolnienia-spokojnie-doktorze-to-tylko.html.

WóJCiK, Katarzyna. "E-składka bez problemów.” Rzeczpospolita, January 18, 2018. https:// archiwum.rp.pl/artykul/1364215-E-skladka-bez-problemow.html.

ZAKŁAd UbeZPIECZEŃ SPOŁECZNYCh. "E-ZLA - jedyny sposób na wystawienie zwolnienia." $Z$ życia ZUS, no. 11-12 (2017).

ZAKŁAD UBEZPIECZEŃ SPOŁECZNYCH. "Strategia przekształceń Zakładu Ubezpieczeń Społecznych na lata 2010-2012." Warsaw, October 2010. https://www.zus.pl/documents/10182/0/ Strategia $+2010+-+2012 / 61 \mathrm{~d} 9510 \mathrm{f}-241 \mathrm{~b}-4547-8 \mathrm{f} 73-7455 \mathrm{dbf0389c}$.

ZaKŁad UbeZPIECZeŃ SpOŁeCZNYCH. "Strategia rozwoju Zakładu Ubezpieczeń Społecznych na lata 2013-2015." Warsaw, December 2012. https://www.zus.pl/documents/10182/39611/ Strategia + rozwoju + Zak $\%$ C $5 \% 82 \mathrm{adu}+$ Ubezpiecze $\% \mathrm{C} 5 \% 84+$ Spo $\% \mathrm{C} 5 \% 82$ ecznych + na + lata +2 013-2015/6cb0b2d7-2df2-4bc9-b99f-dd8eb46e2848.

ZAKŁAD UBEZPIECZEŃ SPOŁECZNYCH. "Strategia Zakładu Ubezpieczeń Społecznych na lata 20162020." Warsaw, December 2015. https://www.zus.pl/documents/10182/0/Strategia+Zak\% C5\%82adu+Ubezpiecze\%C5\%84+Spo\%C5\%82ecznych+na+lata+2016+-+2020/cd2987fa-68 6c-417a-a351-91904dc5ff84.

ZakŁad UbezPIECZeń SpOŁeCZnych. “Obsługa klientów w ZUS. Polityka 2017-2020. Informacja z 2016 r.” Warsaw 2016.

ZAwICKI, Marcin. Nowe zarzadzanie publiczne. Warsaw: Polskie Wydawnictwo Ekonomiczne, 2011.

OTHER

Uchwała nr 17 Rady Ministrów z dnia 12 lutego 2013 r. w sprawie przyjęcia strategii Sprawne Państwo 2010 [Resolution No. 17 of the Council of Ministers of 12 February 2013 on the adoption of the strategy "Sprawne Państwo 2010"]

www.eskladka.pl (accessed June 3, 2018)

www.zus.pl (accessed June 2, 2018) 


\title{
E-SERVICES VS CONCERN FOR THE IMAGE OF ZUS
}

\author{
Summary
}

The article presents e-actions undertaken by the Social Security Institution (Zaklad Ubezpieczeń Spotecznych, ZUS) - a state-owned institution that accomplishes tasks determined by the law. The aim of this study is to present current e-services offered by ZUS as well as to analyse the influence of the aforementioned services on the image of this institution, which lays great emphasis in its vision and mission statement on customer care and also building trust in this institution. Actions taken by ZUS permit a claim that ZUS is prepared to support customers remotely. The institution responds to signals sent from society and addresses customers' needs by implementing modern communication techniques as well as by educating and popularizing knowledge of social insurance. Critical analyses and results of the statistical research made available by the ZUS Customer Service Department were used in the writing of this article.

Key words: ZUS, e-services; image of ZUS; quality of customer service; customer satisfaction; New Public Management; NPM.

\section{E-USŁUGI A TROSKA O WIZERUNEK ZUS}

\section{Streszczenie}

W artykule przedstawiono działania elektroniczne (e-działania) podejmowane przez Zakład Ubezpieczeń Społecznych (ZUS) - instytucję administracji publicznej, realizującą zadania określone przepisami prawa. Celem tego opracowania jest prezentacja aktualnych e-usług oferowanych przez ZUS, a także analiza wpływu wyżej wymienionych usług na kreowanie wizerunku tej instytucji, która kładzie duży nacisk - w swojej wizji i misji - na opiekę nad klientem oraz budowanie wzajemnego zaufania. Działania podejmowane przez ZUS pozwalają wysunąć tezę, że instytucja ta jest przygotowana do wspierania klientów na odległość. Instytucja reaguje na sygnały wysyłane z zewnątrz i otwiera się na potrzeby klientów, wdrażając nowoczesne techniki komunikacji, a także edukuje i popularyzuje wiedzę na temat ubezpieczeń społecznych. W artykule wykorzystano analizę krytyczną oraz wyniki badań statystycznych udostępnione przez Dział Obsługi Klienta w ZUS.

Słowa kluczowe: ZUS; e-usługi; wizerunek ZUS; jakość obsługi klienta; zadowolenie klienta; nowe zarządzanie publiczne; NPM. 